\title{
„W stronę biografii totalnej?” Buty Ikara Mariana Buchowskiego wobec projektu pisarskiego Edwarda Stachury - szkic krytyczny
}

Niezależnie od tego, czy uznamy „Życiopisanie” ${ }^{\text {w }}$ odniesieniu do twórczości Edwarda Stachury za pojęcie nieadekwatne [Pachocki 2009], czy jedynie za wymagające pogłębienia, sproblematyzowania i redefinicji [Wójcik 1998], to chyba jednak łatwo zgodzimy się, że sam problem relacji między literaturą a życiem stanowi jeden z głównych tematów w twórczości tego autora. Pytania o to, jak stworzyć literaturę żywą, jak wykorzystać własną twórczość, by życie nie tyle opisać, ile po prostu w tekście uobecnićz, spędzały Stachurze sen z powiek. Stąd gdy w obręb intymnego związku, który tego typu autor nawiązuje ze swoim pisarstwem, próbuje przyłączyć się ktoś trzeci, ktoś z zewnątrz (np. biograf) sytuacja sama staje się wyjątkowo ciekawa. Żyjąc na przełomie lat 2014-

1 Kategoria ta została zaproponowana do opisu twórczości Stachury przez Henryka Berezę w artykule Życiopisanie dołączonym do tzw. „dżinsowego wydania” dzieł zebranych autora Siekierezady. Od tamtego czasu wywierała silny wpływ na recepcję pism Stachury, na wiele lat przypieczętowując autobiograficzne interpretacje tego pisarstwa [por. Bereza 1984].

2 Mówiąc o uobecnieniu, mam na myśli szczególny typ reprezentacji, wyłoniony przez Michała Pawła Markowskiego [2012]. 
-2015, mieliśmy szansę stać się bezpośrednimi uczestnikami i obserwatorami takiego właśnie zdarzenia - $\mathrm{i}$ to $\mathrm{w}$ wyjątkowo wyrazistym wydaniu - za sprawą nowej, wydanej w listopadzie 2014 r. książki Mariana Buchowskiego Buty Ikara. Biografia Edwarda Stachury (dalej: Buty Ikara).

Buchowski [1992], próbując w swojej nowej książce stworzyć tekst oparty na faktach z życia autora Siekierezady (a warto już na początku wspomnieć, że to druga próba tego biografa), chcąc nie chcąc, włączył się w grę, którą Stachura rozpocząl przed laty. Mówiąc o „grze”, mam na myśli złożony zespół działań, które Stachura podejmował wobec siebie, wobec czytelnika, a przede wszystkim wobec konwencji literackich. Działania te były nastawione na dokonanie swego rodzaju transgresji i sprostanie niemożliwemu: uobecnieniu w tekście zapisu jednostkowego życia (które należałoby odróżnić od wybiórczej, skonwencjonalizowanej pod względem poznawczym i kulturowym egzystencji). Zgodnie z myśleniem Stachury, aby tego dokonać, trzeba odnaleźć performatywną formułę - formę, która nie tylko pozwoliłaby pochwycić w języku cień istniejącego gdzie indziej życia, ale również wywołałaby jego obecność w samym sposobie zapisu. W wieńczącym tom Falując na wietrze opowiadaniu Roraty Stachura [1984b: 234] przedstawia ten problem w następujący sposób:

Przeszedł mnie chłód, jak ot przed świtem. I on mnie poruszył, a nie dalekie dudnienie pociągu. Na pewno na pierwszym miejscu jest jedna rzecz, którą ciało moje zna na wylot: chłód. Trochę za lekko, zdaje się, trochę za szybko i składnie $\mathrm{mi}$ się o tym powiedziało. Inaczej trochę powinno to być powiedziane, jak na takie zimne wyznanie przystało. Nie tak gładko. Nie tak zgrabnie. Może powinno to być wolno wycedzone albo może lepiej wyjąkane przez szczękające od zimna zęby, a napisane niezdarnie jak przez zgrabiałe od mrozu palce. Bo wymyślić można wszystko i napisać to zgrabnie, jak to jest w pięknej literaturze. To nie jest wielki trud. Można tak bez końca wypełniać wysokie regaly bibliotek, jak to jest właśnie w pięknej literaturze. Chciałem przez to coś powiedzieć, to znaczy chciałem coś powiedzieć dalej, to znaczy chciałem 
powiedzieć jak to jest, kiedy jest inaczej, kiedy słowa nie mają padać zgrabnie, tylko... i tu brak mi słów. Ale wiedzą dobrze i tak ci, którzy wiedzieć chcą, o co ja tu kruszę chleb.

Ten fragment dotyczył próby utrwalenia w opisie jednego doświadczenia - doświadczenia chłodu, a i tak liczne kłopoty z tym związane zaprowadzily Stachurę na same granice języka. Łatwo zrozumieć, że przedsięwzięcie zakrojone na o wiele większą skalę - chęć opisania wszystkich doświadczeń, a więc całego życia - wymagało znacznie szerszego myślenia i wyszukiwania bardziej skomplikowanych rozwiązań. Próby odkrycia tego typu sposobu wyrażania - pisania, które byłoby w stanie uobecnić życie - stanowiły jeden z konstytutywnych elementów, na których ufundowana została większa część twórczości Stachury. Na kartach jego prozy można znaleźć wiele fragmentów świadczących o poszukiwaniach autora, będących różnego rodzaju odpowiedziami na ten sam pisarski problem. Jedna z pierwszych, a zarazem istotniejszych (bo rozwijanych i problematyzowanych w późniejszej twórczości) recept Stachury [1984a: 24] na rozwiązanie tego problemu była u swoich podstaw stosunkowa prosta i zarazem wyjątkowo karkołomna: zapisać wszystko - czy właściwie: zapisać wszystko z siebie:

Wypchnąć wszystko z siebie, co się jeszcze opiera, wypluć, wykrztusić, wycharczeć z bólem, zdobyć się, zdobyć się na to, by wyrzec się wszystkiego, wypuścić z klatki wszystkie oddechy na wolność straszliwą, na drogi, na szlaki i tam dalej i tam dalej, i niech tam, kiedy już nas nie będzie, niech tam wiecznie kołują, niech tam wiecznie płyną

Projekt pisarski zadeklarowany przez bohatera prozy Stachury miał charakter jawnie maksymalistyczny, do pewnego stopnia wręcz nieludzki. Nakierowany był na bolesne niemalże przelewa-

3 Podkreślam raz jeszcze, że to jeden z pierwszych pomysłów Stachury na zapisanie siebie - z czasem pojawiło się ich więcej, ewoluowały. Tę koncepcję przywołuję ze względu na jej wyrazisty i funkcjonalny charakter. 
nie się żyjącego podmiotu na papier, wtłaczanie się w literaturę. Nie chodzi tutaj oczywiście o naiwny autobiografizm jako konwencję, ale o chęć znalezienia łączności między życiem a literaturą, czy wręcz zrównania życia i literatury, ale z myślą o życiu. Osiągnięcia za pomocą totalności opisu egzystencjalnej pełni, która usunęłaby rozdźwięk między słowem a doświadczeniem i umożliwiłaby zaistnienie idealnej komunikacji. Z tych postulatów - mówiąc w dużym uproszczeniu - wyrosła znaczna część twórczości Stachury, jaką znamy: skoncentrowana na postaci głównego bohatera, który jednak wciąż próbuje przekroczyć wyznaczane przez własną świadomość granice, eksperymentująca z językiem, poszukująca nowych środków wyrazu i form, uwikłana w niekończącą się pogoń za wiecznie wymykającym się ostatecznym sensem.

Buchowski, który na rozmyślanie o życiu Stachury poświęcił pewnie tyle samo czasu co sam zainteresowany, przyjął wobec zadania uobecnienia twórcy nieco inną, choć nie tak znowu odległą postawę. Wynika ona oczywiście z diametralnie różnej pozycji, jaką biograf w tej sytuacji przyjmuje wobec przedmiotu opisu. Nie oznacza to jednak, że kiedy staje w obliczu zadania uobecnienia jednostkowego życia, decyzje, które podejmuje, metody, które wykorzystuje, i odpowiedzi, których w związku z tym niejako pośrednio udziela, są łatwiejsze albo mniej wartościowe. Głos Buchowskiego i wybory, jakie podjął, pisząc biografię Stachury świadomie lub nie - wchodzą w dialog z rozumieniem życia i sposobami jego uobecniania, które w swojej twórczości zaproponował pisarz. Co więcej, przedstawiając literackiemu światu drugą biografię autora Siekierezady, Buchowski polemizuje także z samym sobą sprzed lat - z własnymi poglądami na to, co właściwie znaczy napisać czyjąś biografię, na ile jest to w ogóle możliwe i jak należy to robić.

\section{Narracja bez narratora?}

Pierwsza, chyba najbardziej charakterystyczna cecha, która od razu uderza czytelnika Butów Ikara, to wycofanie i (pozorny) brak silnego, autorskiego „ja” mówiącego. Biografia napisana przez Buchowskiego ma układ chronologiczno-rzeczowy. Jej 
poszczególne rozdziały składają się z setek cytatów, wspomnień, myśli, wrażeń związanych mniej lub bardziej pośrednio z osobą Stachury. Całość została zespojona delikatną, ledwie dostrzegalną nicią autorskiego komentarza. Buchowski najczęściej wyłania się tylko na chwilę, by wprowadzić jedynie kolejny wątek, inny głos w sprawie i za nim zniknąć. Wyraziście zaznacza swoją obecność jedynie w miejscach, w których mówi o własnych doświadczeniach czy wynikach osobistych badań i dochodzeń. W takich okolicznościach uruchamia cały zastaw swoich reporterskich zdolności, które sprawiają, że pewne fragmenty czyta się z zapartym tchem - jak dobry romans czy kryminał. Programowo jednak autor biografii stara się pozostawać w cieniu. To znacząca i wyrazista decyzja. Buchowski znał Stachurę osobiście, a o jego życiu wie więcej niż ktokolwiek inny. Nie trudno więc wyobrazić sobie, że mógłby uczynić siebie drugim głównym bohaterem tej pokaźniej, bo liczącej sześćset stron książki. Tak się jednak nie dzieje. Co więcej - autor świadomie wycofuje się z tworzonej przez siebie narracji. Stara się przyjąć rolę neutralnego, obiektywizującego moderatora, który zestawia ze sobą wiele różnych głosów, pozwala im na swobodny dialog i nie podsumowuje dyskusji żadnym wyrazistym komentarzem.

Tak poprowadzona narracja staje się bardzo cenna z punktu widzenia stachurologii (jeżeli zgodzimy się, że możemy mówić o takim zjawisku). Umożliwia wchłonięcie, pomieszczenie i uporządkowanie ogromnej, narastającej przez lata liczby poglądów, stanowisk, sposobów odczytywania i interpretowania twórczości Stachury. Wcześniej nie istniała żadna plaszczyzna umożliwiająca spotkanie i konfrontację tej wielości głosów, wyciągnięcie dalej idących, ogólniejszych wniosków (ze świecą można szukać konferencji poświęconych Stachurze i jego twórczości!). Buchowskiemu to się udaje. W Butach Ikara tworzy swego rodzaju panoramę, przegląd sposobów recepcji i tendencji interpretacyjnych twórczości Stachury od początku jej zaistnienia w życiu literackim. Choć zestawienie to jest $\mathrm{z}$ konieczności niepełne i silnie naznaczone piętnem genetycznego oglądu relacji między życiem a twórczością pisarza, to i tak staje się krokiem milowym w badaniach nad jego dorobkiem literackim. Zestawienie i omówienie tych wątków pozwala zapo- 
znać się z dziejami recepcji twórczości Stachury bez konieczności przedzierania się przez dziesiątki nieistniejących już najczęściej czasopism w poszukiwaniu krótkich, silnie biografizujących i ostatecznie niewiele wnoszących interpretacji, o które - mam wrażenie - przez długi czas rozbijała się większość badań nad dorobkiem tego autora. Można mieć nadzieję, że praca Buchowskiego pozwoli nareszcie odrzucić paradygmat czytania twórczości Stachury przez pryzmat jego osoby. Umożliwi zwrot ku odczytaniom zupełnie zaniedbanym, skupiającym się na analizie tekstów i sytuującym je w kontekście problemów istotnych z punktu widzenia literatury i kultury xx w. Tym bardziej że, jak można wnioskować po lekturze Butów Ikara, pracy do wykonania jest sporo.

W swojej książce Buchowski wskazuje na istnienie wielu wciąż niezbadanych pól w obrębie badań nad twórczością Stachury. Niewiele jest opracowań dotyczących juweniliów Stachury, jego piosenek i działalności piosenkarskiej jako świadomego wyboru i alternatywy wobec gestu pisania poezji. Tekst Wszystko jest poezja nie doczekał się jeszcze nawet rzetelnej definicji gatunkowej, choć od lat wszyscy badacze zgłaszają problem w tej materii. Słabo opracowane są dzienniki Stachury. Komentarz do nich stworzył jedynie Dariusz Pachocki [2007], ich redaktor i wydawca. Najdotkliwszą, bo najbardziej palącą luką w badaniach nad Stachurą i jego twórczością jest jednak brak refleksji dotyczącej translatologicznej twórczości autora Siekierezady. Stachura był z wykształcenia romanistą, od urodzenia biegle znał francuski, później w podobnym stopniu opanował hiszpański. Od zawsze egzystował na pograniczu języków, a istotne teksty w jego życiu - jak wynika z lektury dzieła Buchowskiego - również wokół tego pogranicza oscylowały. Na swoim koncie ma więcej przekładów niż wierszy (był autorem i współautorem przekładów zarówno poezji, jak i prozy). Był ambasadorem hiszpańskojęzycznych literatur w Polsce i literatury polskiej w krajach Ameryki Łacińskiej. Działalność to imponująca, ale wiele więcej, niestety, na jej temat powiedzieć nie można, bo naukowych głosów w tej sprawie w zasadzie brak. Ot, kolejna $\mathrm{z}$ wielu ślepych plamek na oku historii literatury polskiej.

Chęć zachowania neutralności i pozorów niezaangażowania ma, oprócz wielu zalet, w wydaniu Buchowskiego jednak i swoje 
negatywne oblicze. To właśnie, jak się zdaje, w skutek tego dążenia w pracy Buchowskiego zabrakło tak istotnego elementu, jak wstęp czy posłowie. To chyba moment, w którym owo niezaangażowanie i wycofanie przekracza granicę neutralności i niebezpiecznie wychyla się w stronę... no właśnie: czego? Trudno posądzić Buchowskiego o złe intencje, ale taka sytuacja z pewnością nie służy badawczej rzetelności. Brak jakichkolwiek informacji czy wyjaśnień dotyczących zamiarów autora, wstępnych założeń i sposobu ich realizacji stanowi poważny mankament, jeżeli chodzi o ideologiczny wydźwięk tej pracy. Czytelnik nie dowiaduje się niczego o zasadach selekcji i porządkowania materiału, nie wie, jak nowo powstała biografia sytuuje się wobec poprzedniej, powstałej dwadzieścia dwa lata wcześniej (co więcej, może właściwie zupełnie przeoczyć fakt, że Buchowski był autorem podobnej pracy). Pominięcie odautorskiego komentarza, brak obudowy w postaci pratekstu, silnie sytuuje Buty Ikara po stronie obiegu literatury popularnej. Choć biografia Buchowskiego w istocie do tego kręgu literatury się zalicza i często świadomie, z zyskiem dla prowadzonej narracji korzysta z jej dobrodziejstw (np. poprzez odwołania do konwencji bez mała kryminału czy romansu albo budowanie barwnych opisów osób i miejsc), to jednak zdradza również pewne ambicje badawcze, a na pewno stanowi bardzo istotne źródło informacji dla wszystkich badaczy twórczości Stachury. Patrząc z tej perspektywy, ideologizacja przekazu, charakterystyczna dla obiegu popularnego, z pewnością jej nie służy.

Brak odautorskiego komentarza sprzyja wytwarzaniu przeświadczenia, że przedstawione dzieło jest oczywiste i broni się samo, że nie można sobie wyobrazić innej biografii Stachury, że ta jedna ukazuje prawdę o pisarzu. Tymczasem, rzecz oczywista wcale tak nie jest. Mimo złudzenia obiektywności i wychylenia w stronę dialogu całość została precyzyjnie zaprojektowana przez autora, który zdecydował się na taki, a nie inny dobór cytatów i komentarzy, tych, a nie innych osób, przedstawionych w takiej, a nie innej kolejności. Choć Buchowski stara się nie zdradzać swojego stosunku wobec opisywanych faktów i przytaczanych wypowiedzi, to jednak daje się wyczuć, że jego postawa nie jest bez znaczenia i wywiera istotny wplyw na ostateczny kształt wizji 
życia Stachury, zaproponowanej czytelnikowi w Butach Ikara ${ }^{4}$. Wątpliwości budzi również brak odniesienia do poprzedniej pracy o życiu autora Całej jaskrawości. W efekcie nie wiadomo, czy Buty Ikara należy traktować jedynie jako jej aktualizację, czy też książka ma status istotnej reinterpretacji poprzednich ustaleń. A może w ogóle jest zupełnie nowym spojrzeniem na sprawę? Trudno więc odpowiedzieć na pytanie, za co właściwie płaci czytelnik, który decyduje się na zakup nowej książki Buchowskiego: za kosmetyczne poprawki czy nowe odkrycia i znaczące reinterpretacje?

Publikacja Buchowskiego wpisuje się w żywo rozwijający się $\mathrm{w}$ ciągu ostatnich kilku lat nurt dokumentalistyki skoncentrowanej na życiu i twórczości Stachury. Od roku 2006 za sprawą edytorskich zabiegów Dariusza Pachockiego drukiem pojawiały się kolejno: listy Stachury do pisarzy, jego listy do Danuty Pawłowskiej i zebrany w dwu tomach dziennik. Buty Ikara są niejako naturalnym dopełnieniem tego ruchu, który w stachurologii wywołały ostatnie ustalenia i opracowanie materiałów od lat zalegających w Muzeum im. Adama Mickiewicza w Warszawie. Praca Buchowskiego jest więc na najbardziej podstawowym poziomie próbą połączenia dawnej wiedzy z nową, zarysowania panoramy poglądów, opinii i ustaleń dotyczących Stachury, jakie narastały przez ponad sześćdziesiąt lat, a więc od samego debiutu poety. Do pewnego stopnia nowa biografia jest więc aktualizacją stanu wiedzy, ale aktualizacją nie byle jaką. Książka uderza bowiem swoją rzetelnością, skrupulatnością, niespiesznym, acz konsekwentnie realizowanym postanowieniem, by oko i słowo biografa otarło się o każdy, najdrobniejszy nawet aspekt życia autora Całej jaskrawości. I tak Buchowski nie tylko zajmuje się sprawami najmniejszymi, a szalenie istotnymi, jak na przykład

Zdarzają się momenty, w których ten projekt zdystansowania i dążenia od obiektywności pęka i na powierzchnię tekstu wynurza się z całą siłą krytyczny stosunek Buchowskiego wobec pewnych opinii czy faktów. Najlepiej obrazuje to krótki akapit, w którym biograf pozwala sobie opuścić gardę i podsumować fragment dotyczący obecności Stachury w zapiskach i twórczości Rafała Wojaczka: „I tak to dzielny, bezkompromisowy, mający w nosie konwenanse Piotr Sobecki [alter ego Wojaczka w jego prozie - B.S.] z tchórzliwym, nieśmiałym przypochlebcą Toruńskim [alter ego Stachury w tej prozie - B.S.] pomagali Rafałowi Wojaczkowi leczyć kompleksy" [Buchowski 2014: 99]. 
ustalenie dokładnej daty debiutu młodego Stachurys. Porusza też kwestie kluczowe, zupełnie podstawowe, które do tej pory w omówieniach nie były obecne, a więc: relacje Stachury z władzami PRL, powody obojętności autora Siekierezady na socjalistyczne realia i jego wyraźnego zdystansowania wobec literatury zaangażowanej czy historię związków Stachury z kobietami.

\section{Przeciw mitom i legendom}

Realizując swoje zadanie, Buchowski odwołuje się do techniki prowadzenia narracji, którą opanował wcześniej, w swojej pierwszej książce Edward Stachura. Biografia i legenda. Już podczas jej tworzenia wykorzystywał metodę tkania polifonicznej opowieści, która naświetlałaby dany problem równocześnie z wielu różnych stron. Poprzednia książka Buchowskiego była podzielona na trzy części, wyraźnie oddzielające biografię od wspomnień o poecie i omówień jego legendy. W Butach Ikara biograf zrezygnował z takiego podziału. Starając się na równych prawach wpleść wszystkie wypowiedzi dotyczące Stachury w obręb jednej narracji. Paradoksalnie jednak to pierwsza praca Buchowskiego silniej przyczyniła się utrwalenia mitów i legend na temat Stachury, ponieważ w gruncie rzeczy z takiego legendarnego myślenia wyrastała. Choć autor przywoływał w niej wiele różnych głosów, to ostatecznie skupiał się na poszukiwaniu jedności, punktu zaczepienia, który można by nazwać autentycznym życiem Stachury.

W Butach Ikara daje o osobie znać tendencja wprost przeciwna. Buchowski w zawieszeniu pozostawia pytanie o istnienie jednego, „prawdziwego” Stachury, o to, jaki był naprawdę, która z wygłaszanych na jego temat opinii jest mniej lub bardziej trafna. Autor biografii wyraźnie zwraca się ku ruchowi polegającemu na eksponowaniu różnic, wewnętrznych sprzeczności w wizerunku Stachury. Skupia się próbach wydobycia jak największej liczby jego twarzy, które przez lata zostały utrwalone we wspomnieniach przyjaciół, pisarzy i krytyków literackich.

5 Do tej pory błędnie zakładano, że Stachura zadebiutował w połowie roku 1957. Buchowski [2014: 60] natomiast sygnalizuje, że Stachura debiutanckie wiersze opublikował już w pierwszym numerze czasopisma „Helikon” z 3 grudnia 1956 r. 
Takie podejście do postawionego zadania dookreśla sposób, w jaki Buchowski myśli o problemie zapisywania życia. Skłania się ku konceptom zakładającym, że życie ujawnia się zawsze jednie w narracji, nigdy bezpośrednio. Stąd też drogą do jego najpełniejszego uobecnienia po latach jest zebranie głosów, wspomnień, opowiadań i anegdot, które się na nie złożyły. Wszystkie te mikronarracje nie muszą jednak splatać się w jedną spójną opowieść, umożliwiającą dotarcie do obrazu Osoby. Wręcz przeciwnie, takie dążenie ma pokazać, że nie ma i nigdy nie było jednej osoby i jednego życia Stachury; że właściwie było ich wiele - w różnym czasie, $\mathrm{w}$ różnych sytuacjach i relacjach $\mathrm{z}$ różnymi ludźmi Stachura okazywał cały wachlarz tendencji i zachowań, a każde z nich było na swój sposób ciekawe. Przyjęcie takiej postawy może być podyktowane silnym dążeniem autora Butów Ikara do demitologizacji postaci Stachury, a przynajmniej do rozbicia tych mitów, które szkodziły i nadal często szkodzą recepcji jego twórczości i badaniom nad nią.

Rozważywszy relacje między pierwszą a drugą biografią napisaną przez Buchowskiego, można więc powiedzieć, że biograf do pewnego stopnia powtarza swoją metodę sprzed lat, tyle że wprowadza w niej pewne istotne modyfikacje. Przede wszystkim zmienia leżące u jej podstaw założenia, stosuje ją na większą skalę, wytęża oko na szczegóły, zwraca uwagę na elementy problematyczne czy pomijane we wcześniejszych badaniach. Choć przysłuchując się polifonicznej narracji Buchowskiego, wciąż trudno oprzeć się wrażeniu, że za całością stoi wielki narrator pociągający za sznurki cytatów i nadający odautorski rys całej opowieści, to jednak w nowej książce jest o wiele więcej miejsca na inność, niespójność i wielorakość. W efekcie i tak otrzymujemy więc Stachurę widzianego oczami Buchowskiego, ale tym razem jest to Buchowski zdystansowany, dojrzalszy i bardziej otwarty na irracjonalność życia i dyskursu.

Wiele wysiłku autor Butów Ikara wkłada (ten wątek w zasadzie otwiera książkę) w uporządkowanie i wyjaśnienie kwestii dotyczących relacji Stachury z władzą w czasach Polski Ludowej oraz rozpoznanie powodów, dla których autor Siekerezady pozostawał zdystansowany wobec literatury zaangażowanej - tworzonej 
zarówno przez zwolenników, jak i przeciwników partii w tamtym czasie. Temat ten od lat pozostawał nieopracowany i jako miejsce puste w dyskursie stał się źródłem plotek i pomówień, które być może - zrażały, a przynajmniej zniechęcały do lektury niektórych badaczy i czytelników. Niejasny status Stachury wobec obowiązującej władzy, brak zaangażowania w krytykę panującego ustroju i liczne zagraniczne wyjazdy pisarza - to wszystko budziło kontrowersje i podejrzenia. Krążyło wypowiadane półsłówkami przekonanie, że taki pięknoduch jak Stachura nie byłby w stanie załatwić pewnych spraw, jeśli nie współpracowałby z władzą. Tymczasem było inaczej.

Buchowski pokazuje, w jaki sposób Stachura nauczył się wykorzystywać swoje rozległe znajomości i procedury socjalistycznego państwa, by dostawać to, na czym mu zależało, nie zostając przy tym niczyim dłużnikiem. Peanów na cześć władzy nie pisał. Polityka w ogóle niewiele go interesowała (co nie znaczy jednak, że nie był świadomy sytuacji politycznej w Polsce). I nie chodzi bynajmniej o uciekanie przed tematyką społeczną w domenę estetyzmu i poezji - co często Stachurze zarzucano ze względu na jego krótki epizod z Orientacją Poetycką Hybrydy - tylko o świadomą próbę opisania, jak funkcjonuje człowiek na innym, nieco głębszym poziomie - tam, gdzie nie konfrontuje się z kulturą. Dlatego Buchowski pokazuje, do jak wielkich nieporozumień doprowadzały próby mierzenia twórczości Stachury za pomocą politycznych i społecznych kryteriów oceny. Zaślepieni nimi krytycy - po obu stronach barykady - chętnie czytali opowiadania Stachury jako relacje z pozbawionej politycznych realiów krainy szczęśliwości, będącej ideologiczną pochwałą systemu. Tymczasem, jak wskazuje jeden z głosów przywołanych przez Buchowskiego, „Bohaterowie Stachury uczestniczyli w pełni w życiu PRL - ale na swoich zasadach" [Markiewicz 1996: 194].

Stachura nie chciał i nie mógł angażować się w żadne polityczne układy; nie chciał wikłać się w sieci ideologii, ponieważ każde zaangażowanie w projekt polityczny, w utarty, narzucony, ogólnie przyjęty społecznie schemat opisywania rzeczywistości, przeszkadzałoby w realizacji projektu egzystencjalno-epistemologicznego, który był dla niego priorytetem. Autor Siekierezady 
pozostawił na boku narracje polityczne. Wolał zwrócić uwagę na znacznie głębiej sytuujący się problem: zniewolenie ówczesnego człowieka nie tyle przez reżim polityczny, ile przez ograniczenia, które (zwłaszcza w tamtym czasie) na jednostkę nakłada kultura - kultura protez i schematów poznawczych. Stąd - mówił Stachura - aby człowiek mógł uwolnić się spod władzy innych, musi zerwać obezwładniające go więzy kultury, w której przyszło mu żyć. Zatem w gruncie rzeczy najpierw powinien uwolnić się spod władzy samego siebie: własnych ograniczeń i własnego zaślepienia, własnego wygodnictwa, własnej bezrefleksyjności. Paradoksalnie więc twórczość Stachury mogła przyczynić się i być może przyczyniała się - do walki z obowiązującym system o wiele bardziej, niż mogłoby się wydawać.

Problem stanowiła jednak recepcja pism Stachury. Ich misterna, zawiła konstrukcja, niekonwencjonalny, nieprzejrzysty, zaciemniający całość język, połączone z obowiązującymi w tym czasie kanonami czytania literatury, sprawiały, że twórczość tę odbierano powierzchownie. W efekcie powstała ciągnąca się latami czarna seria jej niedoczytań, lektur częściowych, prześlizgujących się po bardziej złożonych, często nowatorskich pomysłach i rozwiązaniach formułowanych wobec najbardziej palących pytań europejskiej literatury i filozofii po II wojnie światowej (problemu niewyrażalności, kwestii zacierania się granicy między fikcją i literaturą świadectwa osobistego, pomysłu na budowanie przestrzeni komunikacyjnej po wojennej traumie i korzystania z słów w sytuacji nieobecności metafizycznego sensu). Wielu odbiorców przeczuwało tę wartość, która umykała uwadze krytyki. Mówiło się o fascynacji tą prozą, o jej „magii”, brakowało jednak języka do jej nazwania i zrozumienia.

Dekonstrukcji Buchowski poddaje również inne mity. Pokazuje Stachurę jako człowieka zaradnego, obrotnego, który potrafi zadbać o swoje sprawy - zrywa więc z mitem bujającego w chmurach wagabundy. Biograf wiele uwagi poświęca również życiu domowemu i rodzinnemu poety - tym samym nadwyręża jego obraz jako wiecznego tułacza, człowieka sypiającego jedynie kątem u przyjaciół i znajomych. Rozbija mit samodzielności i niezależności Stachury, ukazując, jak wiele zawdzięczał wsparciu rodziny, 
przyjaciół i życzliwych mu osób. Uświadamia czytelnikowi, jak trudnym i czasami bezwzględnym w obyciu człowiekiem bywal. Buchowski pokazuje twarz Stachury wytrawnego pokerzysty i Stachury poszukującego pocieszenia w alkoholu. Dementuje plotki, jakoby pisarz był kobieciarzem i uwodzicielem, akcentując jego wierność wobec partnerek życiowych. Problematyzuje jednak kwestie mizoginizmu, który zarzucano autorowi Siekiere$z a d y$. Dokładnie bada przebieg wkraczania Stachury w tzw. „okres mistyczny" i ukazuje momenty, kiedy jednolity obraz autora Oto jako natchnionego, oderwanego od świata mistyka nieco pęka. Dzieje się tak między innymi, gdy poeta bardzo trzeźwo i zaradnie zabiega o publikację i rozprowadzenie swoich pism, próbuje dotrzeć do pożądanego grona odbiorców, w końcu nawet przeredagowuje rzekomo „natchnione” i tym samym nienaruszalne teksty.

Rozprawa z mitami dotyczącymi Stachury została zakrojona w Butach Ikara na szeroką skalę. Wiele mitów narosłych wokół autora Siekierezady wymagało jednak obnażenia. Co ciekawe, do ich utrwalenia w pewnym stopniu przyczyniła się pierwsza biografia pióra Buchowskiego. Jej następczynię można więc odczytywać jako ruch autokorekcyjny, swego rodzaju subtelne rozliczenie się z dawnymi przemyśleniami i próbę ustanowienia nowego, bardziej aktualnego i mniej zawłaszczającego obrazu Stachury.

\section{Biografia totalna}

Podczas lektury biografii autora Siekierezady napisanej przez Buchowskiego można jednak odnieść wrażenie, że istnieje płaszczyzna myślenia, która w wyraźny sposób łączy biografa i bohatera jego pracy. Chyba każdy, kto pisał o Stachurze, wie, jak bardzo sugestywnym jest on twórcą i jak trudno w związku z tym zdystansować się wobec jego poglądów, jego języka i jego pisarstwa, by krytycznie je ocenić. Buchowskiemu to zadanie na poziomie krytykowania mitu, który tworzył wokół siebie autor Siekierezady, wychodzi świetnie. Biograf z wielką wprawą obnaża zabiegi mitotwórcze Stachury, pokazuje genezę i rozwój jego poglądów, podważając tym samym mit jego samoistności. Stara się akcentować, wydobywać i opracowywać słabości twórcy, które on sam próbował 
okrywać szczelnym płaszczem własnego pisarstwa. Buchowski robi to bez sentymentów, bardzo konsekwentnie i przekonywająco - nie pozostawiając żadnych wątpliwości, że na tym poziomie rzetelnie odrobił lekcję z dystansu. Inaczej sprawa wygląda, jeżeli chodzi o krytyczne usytuowanie się wobec pisarskich osiągnięć Stachury. Widać bowiem wyraźnie, że Buchowski dzieli ze swoim bohaterem przekonanie, w myśl którego opisywać życie człowieka znaczy opisać je w całej pełni, ze wszystkimi szczegółami, uwzględniając wszystko. W efekcie biografia Buchowskiego - podobnie jak pisarstwo Stachury - wychyla się w stronę totalności'. Trudno właściwie ocenić, na ile jest to przejaw ulegania wpływom Stachury, a na ile próba stworzenia przemyślanego, intymnego związku pomiędzy biografią i jej bohaterem, pisarzem i jego biografem. Niewątpliwie można jednak stwierdzić obecność takiego zjawiska w pracy Buchowskiego i wskazać na jego mocne i słabe strony.

Nawet jeżeli autor Butów Ikara do pewnego stopnia ulega czarowi koncepcji opisywania i uobecniania życia zaproponowanej przez Stachurę, to jednak w znaczny sposób ją rozszerza. Inaczej definiuje bowiem opisywane przez siebie życie. Bardziej niż jednostkowe, egzystencjalne przeżywanie i doświadczanie świata Buchowskiego interesuje życie funkcjonujące w kontekście społecznym. Swój opis rozpoczyna więc jeszcze przed narodzinami Stachury i nie urywa go wraz z fizyczną śmiercią autora. To właśnie wszelkie przejawy życia społecznego autora Siekierezady - utrwalone w dokumentach, wspomnieniach, świadectwach, notatkach, listach, komentarzach, recenzjach, podaniach - stara się uchwycić Buchowski. Tym samym całościowemu opisowi egzystencjalnemu utrwalonemu w twórczości Stachury przeciwstawia całościowy opis życia zanurzonego w rzeczywistości społecznej, tworząc istotne uzupełnienie tego pierwszego. Decydując się na takie działanie, Buchowski w pewien sposób, pośrednio, wypełnienia lukę, którą Stachura programowo umieścił w swojej twórczości.

6 Pachodzki jest autorem książki Stachura Totalny. Podkreśla w niej tezę, że cała twórczość Stachury jest próbą zapisania wszystkiego. W związku z tym wszystkie jego zapisy (opowiadania, listy, dzienniki) należy traktować pod pewnymi względami równorzędnie i czytać je jako przejaw pewnej zaprojektowanej całości [Pachocki 2007]. 
Autor Butów Ikara z ogromną pieczołowitością gromadzi materiały dotyczące domu i sytuacji społecznej, w której funkcjonował Stachura. Zarysowuje charakter rodziny Stachurów, okoliczności narodzin i dorastania małego Edwarda. Ukazuje kulisy edukacji poety - jego stosunku do nauki i powolnego awansu z rodziny robotniczej do klasy inteligenckiej. Opisuje okoliczności jego debiutu, śledzi pierwsze pisarskie wprawki i znajomości, które mogły ukształtować tożsamość twórczą młodego pisarza. Tym samym Buchowski nadwyręża nieco mit egzystencjalnej samodzielności oraz myślowej i twórczej niezależności Stachury. Ukazuje, jak wiele autor Całej jaskrawości zawdzięczał swoim najbliższym, od których na dalszym etapie życia próbował się odciąć (napisał w tej sprawie stosowny list), oraz jak wiele i jak chętnie uczył się od swoich literackich i filozoficznych mistrzów i przyjaciól, takich jak: Cyprian Norwid, Jarosław Iwaszkiewicz, Julian Przyboś, Rafał Urban, Ziemowit Fedecki, Henryk Bereza, a nieco później Barbara Czochralska, Andrzej Moszczyński i wielu innych. Buchowski omawia rozwój twórczości Stachury, stara się zebrać reprezentatywne głosy krytyków, recenzentów i zwykłych czytelników, by odrysować za ich pomocą dzieje recepcji pism poety. Uwagę poświęca także jego działalności artystycznej ściśle związanej z pracą pisarską i budowaniem własnego wizerunku, często bardzo zdawkowo traktowanej w pracach badawczych. Mam tu na myśli rozdziały poświęcone ukazywaniu Stachury tłumacza, Stachury piosenkarza, Stachury osoby publicznej, która z konieczności musi pojawiać się w radiu i w telewizji (wywiady i rozmowy zapisane na taśmach stanowią właściwie osobny i całkiem bogaty rezerwuar istotnych informacji o pisarzu), a także te omawiające kwestie spotkań literackich i wieczorków autorskich, w których autor Siekierezady brał udział. Czytając Buty Ikara, możemy się zatem dowiedzieć, jak Stachura funkcjonował na co dzień, jak zarabiał, gdzie mieszkał, jak układały się jego relacje z najbliższymi i z kobietami.

Buchowski wiele miejsca poświęcił właśnie na uporządkowanie faktów dotyczących spraw sercowych Stachury. Udało mu się na przykład ustalić tożsamość jego pierwszej miłości - Anny Laury Dzięgo, bohaterki opowiadań z juweniliów i z Jednego dnia. Starał 
się również uporządkować informacje dotyczące relacji Stachury $\mathrm{z}$ dwoma ostatnimi, ponad dwadzieścia lat młodszymi od poety kobietami: Danutą Pawłowską i Martą Kucharską. Nieco mniej nowości pojawia się w wątku dotyczącym małżeństwa Stachury z Zytą Oryszyn. Buchowski zachowuje w tej spawie dużą delikatność, gdyż, jak mówi, stara się uszanować prywatność żony dbającej o wspólne ze Stachurą wspomnienia. Biograf tym samym wskazuje niejako granice swojego całościowego zamiaru.

Totalność biograficznego zamysłu Buchowskiego najpełniej objawia się w jego skrupulatności. Zgodnie z tym, co można wyczytać w jego pracy między słowami, w mniemaniu autora Butów Ikara każdy fakt składający się na biografię Stachury jest równoprawny i równoważny - i jako taki zasługuje, by poświęcić mu odpowiednią dozę uwagi. W efekcie, gdy na horyzoncie życia Stachury pojawia się jakaś nowa postać, jej biografia zostaje przez Buchowskiego pieczołowicie zarysowana, i to w dość szczegółowy sposób. Na przykład gdy Stachura napotyka na swojej drodze Ziemowita Fedeckiego, czytelnik otrzymuje cały szereg informacji o tym, kim Fedecki był, gdzie pracował, kogo znał i z kim się spotykał. A gdy w tejże narracji pojawia się wzmianka, że Fedecki utrzymywał kontakty również z Konstantym Ildefonsem Gałczyńskim, to czytelnik niejako z marszu otrzymuje pakiet informacji o Gałczyńskim jako poecie oraz o jego relacjach z Fedeckim. Wszystko po to, by powiedzieć, że zanim Fedecki zawiózł Stachurę do leśniczówki, w której ten zbierał materiały do Siekierezady, to najpierw pojechał do niej również z Gałczyńskim [Buchowski 2014: 138-147].

Taki sposób konstruowania narracji - polegający na gromadzeniu w zasadzie wszystkich faktów, które w jakikolwiek, nawet luźny sposób z osobą Stachury się wiązały - prowadzi do paradoksalnej sytuacji. Główna postać - co rusz rozbijana kolejnym spojrzeniem, kolejnym głosem, dygresją i anegdotą - nabiera niejednokrotnie bardzo efemerycznych, niekonkretnych kształtów. Stąd czytelnicy, którzy sięgając po Buty Ikara, spodziewają się klarownego, syntetycznego ujęcia życia i twórczości autora Siekierezady, z pewnością się zawiodą. Polifoniczna strategia narracyjna Buchowskiego sprawia, że postać Stachury niejako wyła- 
nia się z kolejnych rozdziałów, które naświetlają kolejne aspekty jego życia. Dopiero po przebrnięciu przez większą część obszernej biografii czytelnik jest w stanie wyrobić sobie jakieś pojęcie o portrecie Stachury, który zaproponował Buchowski. Mówimy tu więc o procesie dość żmudnej lektury, która wymaga dużego zaangażowania.

Jednak wytrwały czytelnik, a zwłaszcza taki, który interesuje się ogólnie historią literatury, a nie tylko autorem Całej jaskrawości, może liczyć na nagrodę. Buchowski, komponując polifonię głosów skoncentrowanych wokół Stachury, przedstawił zarazem stosunkowo szeroko zarysowany, choć posiadający jeden „punkt zapikowania”, wycinek z polskiego życia literackiego lat 50., 60. i 70. xx w. Autor Butów Ikara ukazuje redaktorów najważniejszych w tym czasie pism, mówi o nagrodach literackich i sposobach ich przyznawania, o praktyce i polityce wydawniczej tamtych lat, o władzy i o cenzurze, o relacjach między poetami a redaktorami i redakcjami, o poetyckiej codzienności: spotkaniach autorskich, płacach, wizytach w mediach, stypendiach, wyjazdach (albo ich braku), o życiu społecznym, towarzyskim i rodzinnym w tamtym czasie. A wszystko to - co chyba najistotniejsze - przedstawia nie z ptasiej perspektywy historycznoliterackiego omówienia, ale niejako od „wewnątrz”, w sposób żywy, bo oparty na relacjach świadków i wspomnieniach konkretnych sytuacji. Taki zabieg staje się dodatkowo interesujący ze względu na fakt, że Buchowski opowiada w ten sposób nie tylko o środowisku, w którym obracał się Stachura, ale również o realiach własnego życia. Młodszy zaledwie o kilka lat Buchowski rozwijał się w podobnych okolicznościach i na tym poziomie rys autorski czuć dość wyraźnie. Mówienie o Stachurze wykorzystuje więc, by opowiedzieć też nieco o własnych wspomnieniach i doświadczeniach z minionych lat.

Niełatwo jednak oprzeć się wrażeniu, że próba pogodzenia ze sobą dwu biegunów - opowiedzenia biografii Stachury i naszkicowania panoramy życia społecznego, w którym przyszło mu żyć - wprowadza ostatecznie w rozważania Buchowskiego pewien chaos, rozsadza konstruowaną narrację od środka. Wielość materiału, służąca do opisywania życia Stachury, do charakteryzowania jego czasów i otoczenia, pozbawiona wyrazistego, autorskiego 
gestu selekcji i porządkowania, sprawia, że trudno wyobrazić sobie modelowego odbiorcę książki Buchowskiego. Z jednej strony Buty Ikara wydają się adresowane do szerszego grona odbiorców, zwłaszcza młodszych amatorów literatury, którzy chcieliby przeczytać interesującą historię o życiu ciekawego człowieka albo w najlepszym wypadku dowiedzieć się czegoś więcej o ulubionym pisarzu i jego czasach. Pod tym względem książka Buchowskiego ma miejscami charakter niemalże podręcznikowy. Tłumaczy, czym była cenzura i jak działała, opisuje, jak układały się relacje między pracą pisarską a zaangażowaniem w życie polityczne, jak funkcjonowała Służba Bezpieczeństwa itd. Niejednokrotnie Buchowski wprost sygnalizuje, że istotna część zakładanych odbiorców może należeć do innej niż on generacji i właśnie dla tej grupy należy sporządzić w niektórych miejscach nieco więcej objaśnień. Z drugiej zaś strony szczegółowość rozważań, wielostronicowe przywołania i omówienia krytycznych odczytań twórczości Stachury, streszczanie, podsumowywanie i redefiniowanie stanowisk badawczych na temat jego pisarstwa zaadresowane są przede wszystkim do specjalistów zajmujących się badaniem literatury - a zwłaszcza pisarstwem Stachury. W efekcie powstała książka jest zbyt obszerna i zbyt szczegółowa, by zatrzymać na dłużej uwagę nieprofesjonalnego odbiorcy, a miejscami zbyt ogólna i zbeletryzowana, by nie wywołać grymasu u odbiorcy profesjonalnego.

Próba pogodzenia popularyzującej narracji biograficznej z elementami dyskursu naukowego nie kończy się powodzeniem. Książka Buchowskiego i podjęty przez niego zamysł (czy właściwie forma, w jakiej zdecydował się go zrealizować) ostatecznie więc niejako wymknęły się samemu autorowi. Wypowiedzi, perspektywy, style, punkty widzenia, gatunki i dyskursy, z których składa się książka, przeplatają się, nabierając inercyjnego, wewnętrznego pędu - uniezależniają się od woli twórcy. Polifoniczna narracja niejako wchłania autora do swego wnętrza i w pewnym momencie zaczyna żyć własnym życiem. Być może jest to cena, którą przychodzi zapłacić wszystkim, którzy słowem próbują opanować i opisać całość żywiołu życia. Wraz z nim wciągają na karty swoich tekstów część irracjonalności, nieopanowanego pędu i dynamicznego, samodekonstruującego się ruchu dążącego ku rozpadowi, 
który to życie charakteryzuje i tym samym, paradoksalnie, do pewnego stopnia uobecnia.

Podsumowując, należy zaznaczyć, że książka Buchowskiego to imponujący zapis rzetelnej, wnikliwej, wieloletniej pracy biografa, który postanowił opisać Stachurę niejako na nowo. Dać polskim czytelnikom Stachurę odświeżonego, zdemitologizowanego, którego życie i twórczość nie łączą się w prosty sposób, ale stają się czytelniczym zadaniem do wykonania. I to się autorowi Butów Ikara z pewnością udało. Jego książka nie tylko stanowi podsumowanie historycznych badań nad twórczością i osobą Stachury, ale także jest istotnym głosem wspierającym coraz liczniejsze w ostatnim czasie inicjatywy badawcze, które zaczynają krążyć wokół twórczości autora Siekierezady i rozpoznawać na nowo jego miejsce w powojennej historii literatury polskiej. Wierzę, że Buty Ikara staną się swego rodzaju punktem zwrotnym w niezbyt długiej historii stachurologii; punktem, który pozwoli odrzucić ciężar nazbyt łatwych, biografizujących odczytań pism poety i wyprowadzić je na dobre, na cudne manowce nowej lekturowej i badawczej świadomości.

\section{Bibliografia}

Bereza Henryk (1984), Życiopisanie, w: Edward Stachura, Fabula Rasa.

Z wypowiedzi rozproszonych, Czytelnik, Warszawa, s. 445-465.

Buchowski Marian (1992), Edward Stachura. Biografia i legenda, Magnes, Opole.

Buchowski Marian (2014), Buty Ikara. Biografia Edwarda Stachury, Iskry, Warszawa.

Markiewicz Jarosław (1996), Wprowadzenie do ekstatycznego życia i cierpienia Edwarda Stachury, a także próba teorii tak zwanego obtędu i tak zwanej śmierci, część druga, w: Edward Stachura, Fabula Rasa.

Rzecz o Egoizmie, Czytelnik, Warszawa, s. 194-195.

Markowski Michał Pawel (2012), O reprezentacji, w: Kulturowa teoria literatury. Główne pojęcia i problemy, red. Michała Paweł Markowski, Ryszard Nycz, Universitas, Kraków, s. 287-335.

Pachocki Dariusz (2007), Stachura totalny, Wydawnictwo KUL, Lublin. Pachocki Dariusz (2009), Życio-pisanie, którego nie było, „Topos”, nr 5, s. $70-84$. 
Stachura Edward (1984a), Cała jaskrawość, w: tegoż, Powieści, Czytelnik, Warszawa, s. 7-198.

Stachura Edward (1984b), Roraty, w: tegoż, Opowiadania, Czytelnik, Warszawa, s. 233-441.

Wójcik Mirosław (1998), Człowiek-nikt. Prozatorska twórczość Edwarda Stachury w kontekście buddyzmu zen, Wyższa Szkoła Pedagogiczna im. Jana Kochanowskiego, Kielce.

Borys Szumański

„Towards a total biography?” Buty Ikara by Marin Buchowski in the light of Stachura's writing project - a critical sketch

This critical sketch is dedicated to a new biography of Edward Stachura by Marian Buchowski. A writer like Stachura, whose work is very closely intertwined with his life (at least in his declarations) is a challenging protagonist for a biography. In this article, attempts are made at following the way in which Buchowski tries to bring out another human being in the text. His ideas are juxtaposed and confronted with Stachura's own life-and-art ideas, as to him looking for various methods of recording existence was among the crucial goals of writing. As a result, the thesis is put forward that some sort of a writer's "totality" is a feature linking Stachura and Buchowski. In this context, the biography written by Buchowski is not only of importance to research into Stachura's writing but also a significant countersignature of his work.

Keywords: biography; bringing out; Edward Stachura; maximalism.

Borys Szumański - doktorant w Zakładzie Literatury xx Wieku, Teorii Literatury i Sztuki Przekładu IFP UAM. 